\title{
An economic assessment of lignocellulosic biomass power plants
}

\author{
Javier Menéndez ${ }^{1, *}$ and Jorge Loredo ${ }^{2}$ \\ ${ }^{1}$ HUNASER ENERGIA, 33005 Oviedo, Spain \\ ${ }^{2}$ UNIVERSITY OF OVIEDO, Mining Exploitation Department, 33004 Oviedo, Spain
}

\begin{abstract}
In 2016, electricity generation from solid biomass increased by 0.7 Mtoe in EU, compared with 2015, to 10.3 Mtoe (119.78 TWh), a 7.6\% growth rate. Solid biomass may be used for: i) heating $\&$ cooling and hot water for domestic uses, ii) heating for industrial processes and iii) power generation. Unlike other renewable energy sources (RES), such as wind and solar photovoltaic (intermittent energy sources), solid biomass power plants provide dispatchable energy when needed. Therefore, the security of supply could also be increased. In addition, the use of solid biomass has significant advantages, such as the creation of jobs related to the power plant and collection of raw material used to produce energy. In this paper, an economic assessment of forest biomass power plants is carried out in the Iberian electricity system. According to current Spanish electrical regulation, in which three economic parameters are considered as income (day-ahead market, operation and investment), an economic model has been developed for the regulatory useful life ( 25 years). Investment costs for biomass power plants of 15, 30 and 50 MWe have been estimated. Operation \& Maintenance and fuel costs, considering different prices of wet biomass $\left(50-60 € \mathrm{t}^{-1}\right)$ with a moisture content of $40 \%$ and a lower calorific value of $2.8 \mathrm{MWh} \mathrm{t}^{-1}$ on average, have also been considered in the economic model. Net Present Value (NPV), Internal Rate of Return (IRR) and payback period have been obtained in all scenarios. The results obtained show that a biomass power plant with a power of $50 \mathrm{MWe}$ may produce $337.5 \mathrm{GWh}^{-1} \mathrm{ye}^{-1}$ of net electrical energy using $446.43 \mathrm{kt}^{\text {year }}{ }^{-1}$ of wet biomass. Considering a price of electrical energy of $145 € \mathrm{MWh}^{-1}$ and a woody biomass cost of $0.0178 € \mathrm{kWh}^{-1}$, the NPV and IRR reach 165.6 M€ and $17.63 \%$, respectively.
\end{abstract}

\section{Introduction}

Electricity generation from solid biomass grew from 4.8 Mtoe (55.82 TWh) in 2005 to 9.6 Mtoe (111.65 TWh) in 2015 , driven by, inter alia, the expansion of biomass cogeneration and the conversion of coal-fired power plants to biomass facilities. In 2015, the United Kingdom accounted for $20 \%$ of total electricity generated from solid biomass and Germany accounted for $15 \%$. Finland and Sweden each had shares of $10 \%$. In 2016, electricity generation from solid biomass increased by 0.7 Mtoe, compared with 2015 , to 10.3 Mtoe, a $7.6 \%$ growth rate [1]. Solid biomass may be used for: i) heating \& cooling and hot water for domestic uses, ii) heating for industrial processes, and iii) power generation.

The increase of renewable energy sources (RES) requires energy storage systems such as Pumped-storage hydropower (PSH) and Compressed Air Energy Storage (CAES) systems. To reduce the environmental impacts compared to conventional systems, disused subsurface space (i.e. existing closed underground mines in EU) may be used as underground water and compressed air reservoirs, for UPSH and CAES plants, respectively. [27].

\footnotetext{
Corresponding author: javiermenendezr@gmail.com
}

Fig. 1 shows the renewable energy sources in electricity in EU'28 in the period 2008-2017. The share of renewable energy sources in electricity has increased from $16.97 \%$ to $30.75 \%$ in this period. This was drive especially by growth in onshore and offshore wind power and solar photovoltaic (PV, but also by other RES, such as an increase in solid biomass combustion for electricity purposes.

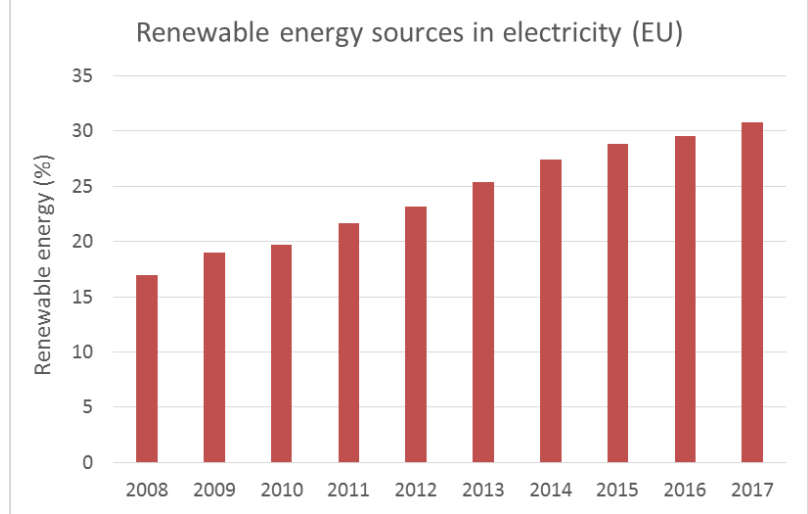

Fig. 1. Renewable energy sources in electricity in EU'28 $(2008-2017)[1]$. 
Some researchers have also studied the use of degraded landscape due to industrial activities (i.e. open pits mines), for the development of short rotation energy crops (SREC) plantations, such as poplar or willow [8,9].

In this paper, an economic assessment of forest biomass power plants is carried out according to Spanish electrical regulation. Biomass power plants with 15, 30 and 50 MWe have been considered in this work. A profitability analysis has been developed for different prices of the wet woody biomass $\left(50-60 € \mathrm{t}^{-1}\right)$. Forest biomass with a moisture content of $40 \%$ and a lower calorific value (LCV) of $2.8 \mathrm{MWh} \mathrm{t}^{-1}$ on average have also been considered. Investment costs and Operation \& Maintenance costs have been estimated during the useful life (25 years). Net Present Value (NPV) and Internal Rate of Return (IRR) were obtained in all scenarios.

\section{Methodology}

\subsection{Forest biomass resources in EU}

Fig. 2 shows the map of aboveground forest biomass in $\mathrm{EU}$ in $\mathrm{Mg} \mathrm{ha}{ }^{-1}$. The forest biomass stocks estimated by Thurner et al. (2014) provided $14 \operatorname{Pg}[10,11]$.

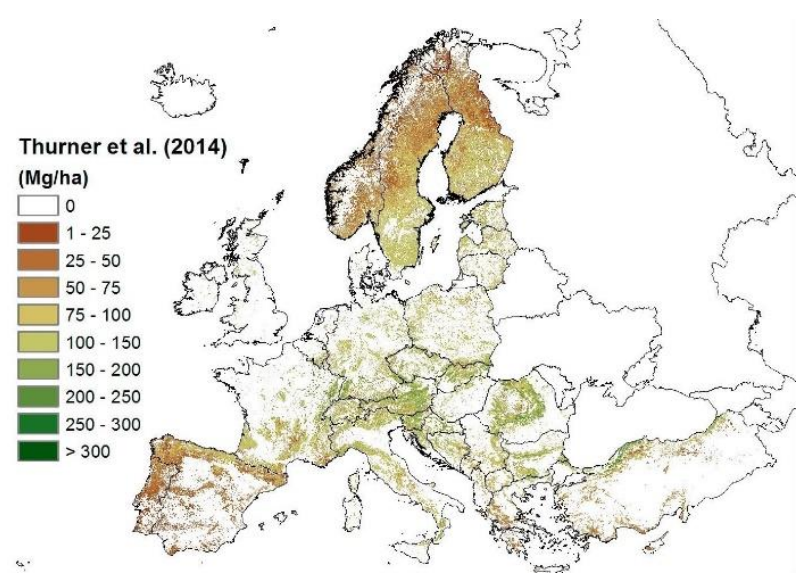

Fig. 2. Map of aboveground forest biomass in EU [10,11].

\subsection{Biomass power plants}

The Rankine cycle is used by biomass power plants to produce electrical energy. This is a thermodynamic cycle which converts heat into mechanical energy which usually gets transformed into electricity by electrical generation. Forest biomass is used to produce heat within a boiler, converting water into steam which then expands through a turbine producing useful work [12,14].

The main components of a biomass power plant are: i) biomass boiler, ii) steam turbine, and iii) biomass treatment and storage plant. The design of biomass boiler depends on the type and quality of forest biomass (pellets, wood chips or wood waste). Mobile grill boilers are typically used in conventional power plants, where wood chips or pellets are used as fuel. Fluidized bed boilers (bubbling or circulating) are used when the quality of the fuel is poor, mainly waste biomass with high moisture content. Biomass power plants with fluidized bed boilers are more expensive, but they can use poor fuels, much cheaper than quality fuels.

Due to the amount of forest biomass required, the logistics of supplying forest biomass should also be thoroughly analyzed [15].

\section{Results and discussion}

\subsection{Energy production and biomass required}

Table 1 shows the gross energy production ( $\mathrm{GWh}$ year $\left.^{-1}\right)$ and the amount of woody biomass required (kt yerar ${ }^{-1}$ ) considering a moisture content of $40 \%$ and a LCV of 2.8 MWh $\mathrm{t}^{-1}$ in biomass power plants with 15,30 and 50 MWe of power. A typical forest biomass power plant, with a power of $50 \mathrm{MWe}$ and 7,500 effective hours of operation per year, could reach up to $375 \mathrm{GWh}_{\text {year }}{ }^{-1}$. A conventional biomass power plant uses up to $10 \%$ of its own electrical output to operate its electrical systems. Therefore, the net electricity production would reach $337.5 \mathrm{GWh}$ year $^{-1}$.

Table 1. Energy production $\left(\mathrm{GWh}_{\mathrm{year}}{ }^{-1}\right)$ and required woody biomass for 15, 30 and $50 \mathrm{MWe}$ of power

\begin{tabular}{ccccc}
\hline $\begin{array}{c}\text { Power } \\
(\mathrm{MWe})\end{array}$ & $\begin{array}{c}\text { Efficiency } \\
(\%)\end{array}$ & $\begin{array}{c}\text { Energy } \\
\left(\mathrm{GWh} \mathrm{year}^{-1}\right)\end{array}$ & $\begin{array}{c}\text { Thermal } \\
(\mathrm{MWt})\end{array}$ & $\begin{array}{c}\text { Biomass } \\
\left(\mathrm{kt} \mathrm{year}^{-1}\right)\end{array}$ \\
\hline 15 & $29.0 \%$ & 112.50 & 51.72 & 138.55 \\
30 & $29.5 \%$ & 225.00 & 101.69 & 272.40 \\
50 & $30.0 \%$ & 375.00 & 166.67 & 446.43 \\
\hline
\end{tabular}

\subsection{Investment and $0 \& M$ costs}

Fig. 3 presents the investment costs for biomass power plants with 15, 30 and 50 MWe of power. A typical biomass power plant with $50 \mathrm{MWe}$ of power (166.67 $\mathrm{MWt}$ ) has an investment cost of 100.56 M€. As shown in Fig. 4, the investment cost per $\mathrm{kW}$ of installed capacity is lower as the power of the plant increases.

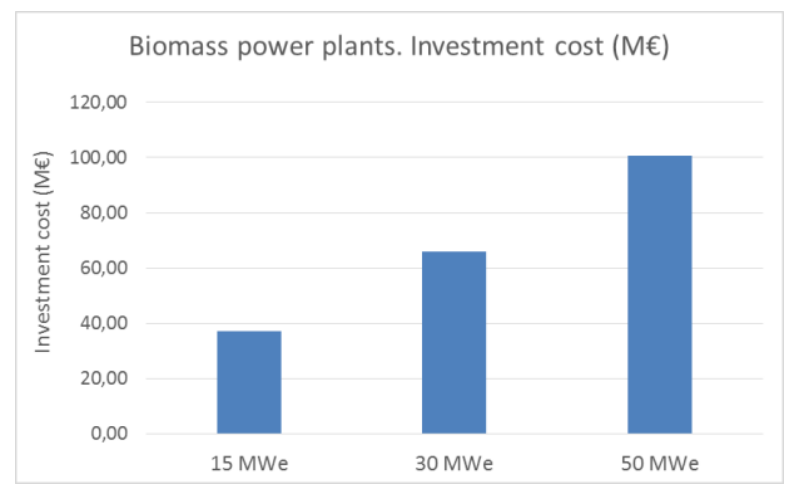

Fig. 3. Investment costs (in M€) of wood forest biomass power plants with 15,30 and $50 \mathrm{MWe}$. 


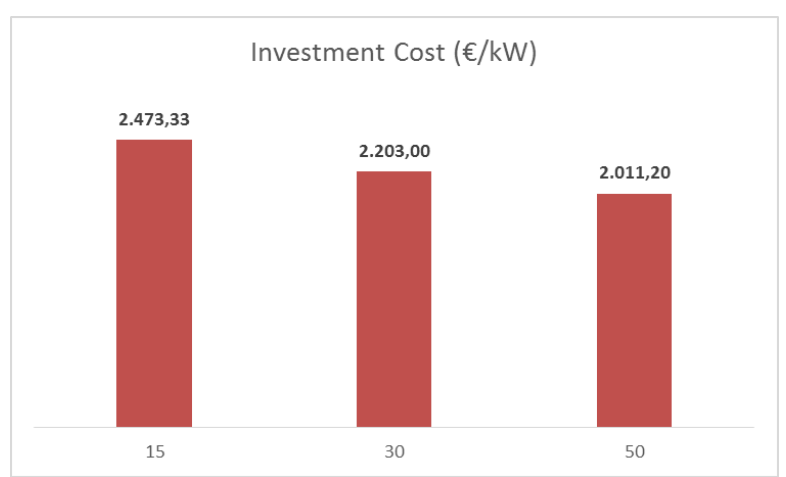

Fig. 4. Investment cost per $\mathrm{kW}$ of installed capacity in biomass power plants with 15,30 and $50 \mathrm{MWe}$ of power.

Fig. 5 shows the summary of investment cost of a forest biomass power plant with $15 \mathrm{MWe}$ of power. The main cost is the supply and installation of the biomass boiler, with a $38.5 \%$ of the total cost.

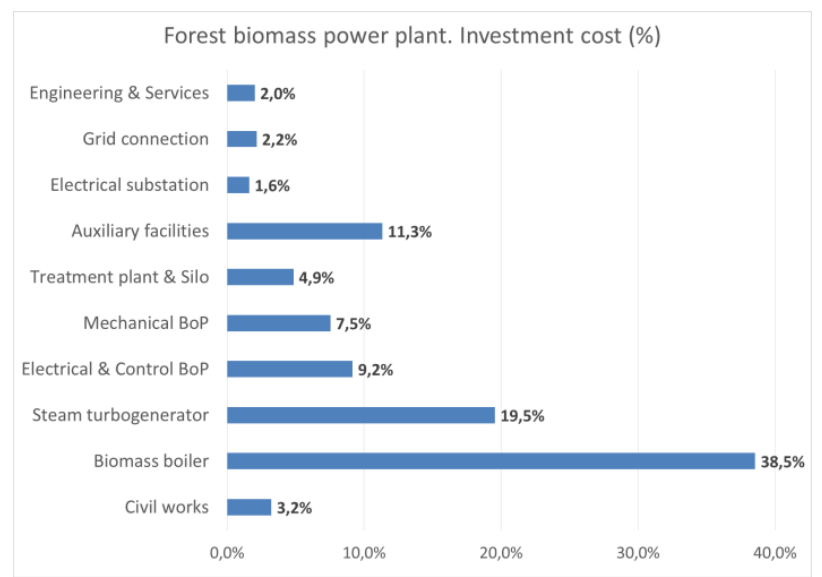

Fig. 5. Investment cost of a forest biomass power plant with 15 MWe. Summary of cost items (\%)

Table 2 shows the investment cost, Operation and Maintenance (O\&M) costs and wet biomass cost for biomass power plants with 15, 30 and $50 \mathrm{MWe}$ of output power. A typical power plant with $50 \mathrm{MWe}$ has a capital cost of $100.56 \mathrm{M} €$ with a fuel cost (wet biomass) of 22.32 $\mathrm{M}$ year $^{-1}$ and an O\&M cost of about 1.8 M€ year 1 .

Table 2. Investment, wet biomass and O\&M costs for biomass power plants with 15,30 and $50 \mathrm{MWe}$ of power.

\begin{tabular}{|c|c|c|c|}
\hline $\begin{array}{l}\text { Power } \\
(\mathrm{MWe})\end{array}$ & $\begin{array}{l}\text { Investment } \\
\text { cost }(\mathrm{M} €)\end{array}$ & $\begin{array}{c}\text { Wet biomass } \\
\text { cost }\left(\mathrm{M} € \text { year }^{-1}\right)\end{array}$ & $\begin{array}{c}\text { O\&M } \\
\left(\mathrm{M}^{-1} \text { year }^{-1}\right)\end{array}$ \\
\hline 15 & 37.10 & 6.93 & 1.20 \\
\hline 30 & 66.09 & 13.62 & 1.40 \\
\hline 50 & 100.56 & 22.32 & 1.80 \\
\hline
\end{tabular}

Fig. 6 shows the summary of income (M€ year ${ }^{-1}$ ) for forest biomass power plants with 15,30 and 50 MWe. According to the Spanish electrical regulation, three economic parameters have been considered, day-ahead market, operation and investment. Total income of 14.73, 29.46 and $49.10 \mathrm{M} €$ year $^{-1}$ are obtained for biomass power plants with 15, 30 and $50 \mathrm{MWe}$, respectively.

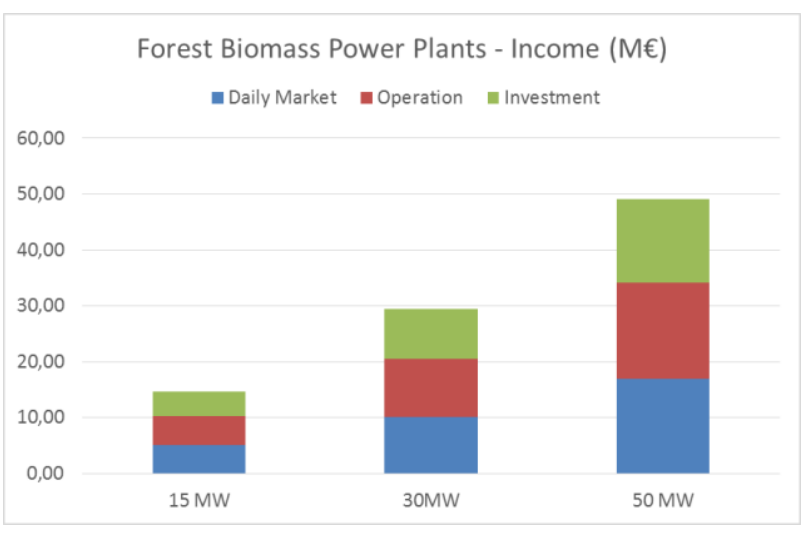

Fig. 6. Summary of income $\left(\mathrm{M} €\right.$ year $\left.^{-1}\right)$. Day-ahead market, operation and investment parameters. Biomass power plants with 15,30 and $50 \mathrm{MWe}$.

\subsection{Profitability analysis}

In this section, the results obtained in the economic model are shown. Table 3 shows the main parameters that have been considered in the economic model.

Table 3. Economic model parameters according to current Spanish electrical regulations.

\begin{tabular}{lc}
\hline \multicolumn{1}{c}{ Economic model parameters } \\
\hline Day-ahead market $\left(€ \mathrm{MWh}^{-1}\right)$ & 50 \\
Operation retribution $\left(€ \mathrm{MWh}^{-1}\right)$ & 53 \\
Investment retribution $\left(€ \mathrm{MW}^{-1} \mathrm{year}^{-1}\right)$ & 300,000 \\
Access tariffs $\left(€ \mathrm{MWh}^{-1}\right)$ & 0.5 \\
Operation time (years) & 25 \\
Equity (\%) & $20 \%$ \\
Debt $(\%)$ & $80 \%$ \\
Loan interest rate $(\%)$ & $3 \%$ \\
Loan term (years) & 15 \\
Amortization (years) & 25 \\
Annual CPI (\%) & $2.0 \%$ \\
\hline
\end{tabular}

Fig. 7 shows the profitability analysis (NPV) for biomass power plants with 15,30 and $50 \mathrm{MWe}$, and woody biomass with a moisture content of $40 \%$ and costs between 50-60€ $\mathrm{t}^{-1}$. A day-ahead price in the Iberian electricity market of $50 € \mathrm{MWh}^{-1}$ has been considered. In a typical biomass power plant with 50 MWe of power and an average of $7,500 \mathrm{~h}$ year ${ }^{-1}$, the NPV is 165.62, 141.42 and 117.22 M€ for a wet biomass cost of 50,55 and $60 € \mathrm{t}^{-1}$, respectively.

Fig. 8 presents the IRR (\%) for biomass power plants with 15, 30 and 50 MWe of power for 25 years of useful life. Considering a biomass power plant of $50 \mathrm{MWe}$, the IRR obtained is $17.63 \%, 15.88 \%$ and $14.10 \%$ for a wet biomass cost of 50,55 and $60 € \mathrm{t}^{-1}$, respectively. If the power of the biomass plant is reduced to $15 \mathrm{MWe}$, the IRR is also reduced to $11.86 \%, 10.26 \%$ and $8.60 \%$ for the three power plants that have been studied. 


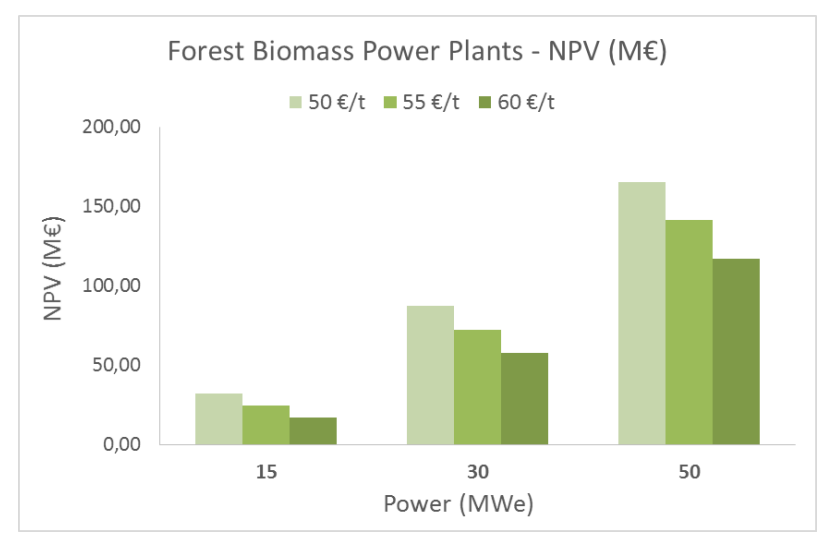

Fig. 7. Profitability analysis. NPV (M€) for biomass power plants with 15,30 and $50 \mathrm{MWe}$ and wet biomass costs of 50, 55 and $60 € \mathrm{t}^{-1}$ (Moisture content: $40 \%$ ).

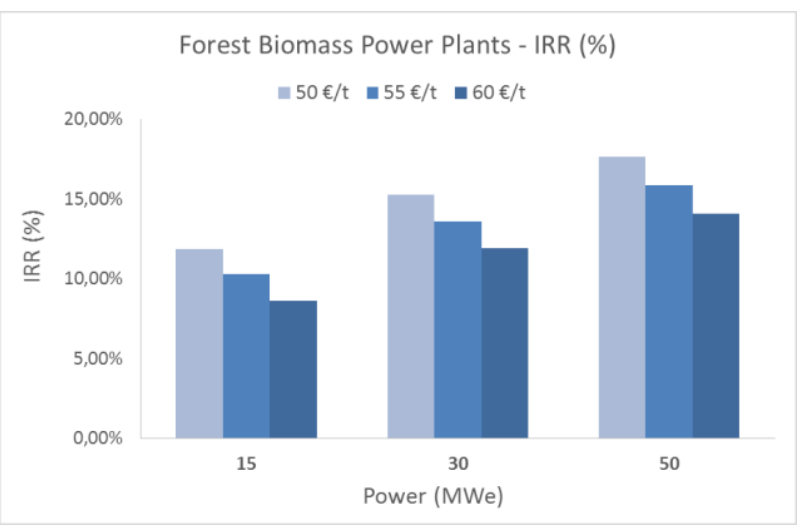

Fig. 8. Profitability analysis. IRR (\%) for biomass power plants with 15, 30 and 50 MWe and wet biomass costs of 50, 55 and $60 € \mathrm{t}^{-1}$ (Moisture content: $40 \%$ ).

If the price of electrical energy is reduced to $103.00 €$ $\mathrm{MWh}^{-1}$ (considering only the price in the day-ahead electricity market and operation parameter), the profitability is seriously affected. Currently, wind and solar PV power plants in Spain operate only with the price of the day-ahead electricity market, that is, $50 €$ $\mathrm{MWh}^{-1}$ on average. Biomass plants need a subsidy to operate, so the energy obtained in these plants is more expensive.

Fig. 9 shows the results obtained for the NPV (M€) considering an electricity price of $103.00 € \mathrm{MWh}^{-1}$. Wet biomass costs of 40,50,55 and $60 € \mathrm{t}^{-1}$ have been considered. If a wet biomass cost of $50 € \mathrm{t}^{-1}$ is considered, the NPV obtained is $-16.60,-8.56$ and 5.98 $\mathrm{M} €$, for 15,30 and $50 \mathrm{MWe}$, respectively. In this scenario, a biomass cost of $40 € \mathrm{t}^{-1}\left(0.01429 € \mathrm{kWh}^{-1}\right)$ has also been analyzed. In this case, the NPV increases up to $-0.94,20.97$ and 54.38 M€ for 15, 30 and $50 \mathrm{MWe}$, respectively.

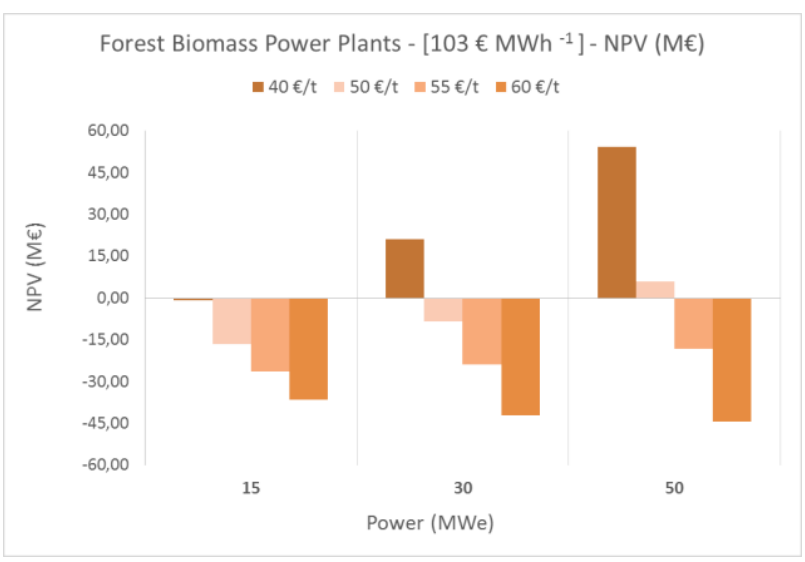

Fig. 9. Profitability analysis. NPV (M€) for biomass power plants with 15,30 and $50 \mathrm{MWe}$, electricity price of $103.00 €$ $\mathrm{MWh}^{-1}$ and wet biomass costs of $40,50,55$ and $60 € \mathrm{t}^{-1}$.

Fig. 10 depicts the results of IRRs (\%) considering an electricity price of $103.00 € \mathrm{MWh}^{-1}$. IRR values are also lower compared to the previous scenario, where an electricity price of $145 € \mathrm{t}^{-1}$ was considered. IRR values increase when the wet biomass cost is reduced to $40 € \mathrm{t}^{-1}$. IRR values of $4.25 \%, 7.38 \%$ and $9.24 \%$ have been obtained for biomass power plants with 15, 30 and 50 MWe of power, respectively. However, if the wet biomass cost increases up to $50 € \mathrm{t}^{-1}$, the IRRs are reduced to $-0.49 \%, 3.21 \%$ and $5.06 \%$, for biomass power plants with 15, 30 and $50 \mathrm{MWe}$ of power, respectively.

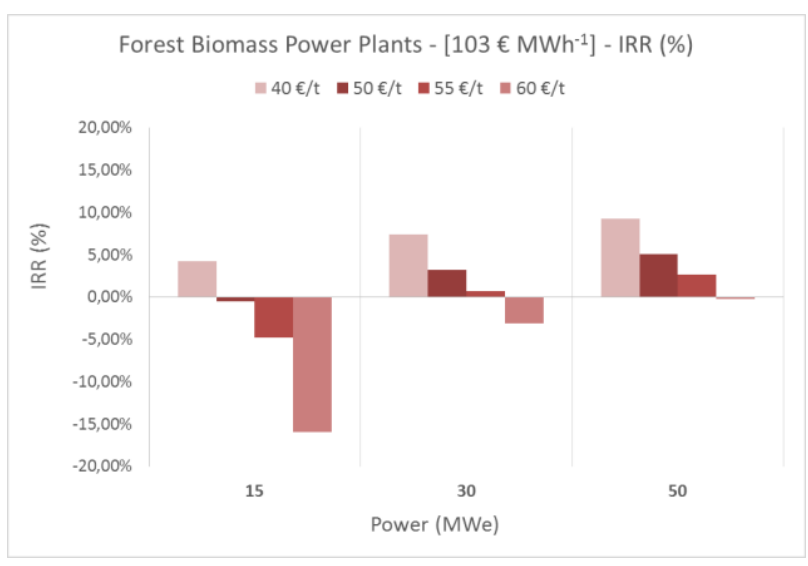

Fig. 10. Profitability analysis. IRR (\%) for biomass power plants with 15,30 and $50 \mathrm{MWe}$, electricity price of $103.00 €$ $\mathrm{MWh}^{-1}$ and wet biomass costs of 40, 50, 55 and $60 € \mathrm{t}^{-1}$.

\section{Conclusions}

Solid biomass power plants provide dispatchable energy when needed. Therefore, the security of supply could also be increased using this technology compared to other renewable energy sources such as wind or solar PV. Spanish electrical regulation considers a subsidy for biomass power plants, with a price for the electricity produced much higher than the price of the day-ahead market. Currently, wind and solar PV power plants operate only with the price of day-ahead market (50-55€ $\left.\mathrm{MWh}^{-1}\right)$. However, biomass power plants have significant benefits, such as the creation of numerous 
jobs related to the power plant and collection of raw material.

An economic model has been developed for the regulatory useful life ( 25 years) in forest biomass power plants with 15, 30 and $50 \mathrm{MWe}$. Investment costs, O\&M costs and fuel (wet biomass) costs have also been considered in the model with an annual Consumer Price Index of $2 \%$.

A biomass power plant with $50 \mathrm{MWe}$ of power may produce $337.5 \mathrm{GWh}$ year ${ }^{-1}$ of net electrical energy using $446 \mathrm{kt}$ year $^{-1}$ of woody biomass. Considering a price of electrical energy of $145 € \mathrm{MWh}^{-1}$ (day-ahead market price, operation and investment) and a woody biomass cost of $0.0178 € \mathrm{kWh}^{-1}$, the NPV and the IRR are 165.6 $\mathrm{M} €$ and $17.63 \%$, respectively. A biomass power plant with $15 \mathrm{MWe}$ of power reaches a NPV of $31.92 \mathrm{M} €$ and an IRR of $11.86 \%$ with a woody biomass cost of 0.0178 $€ \mathrm{kWh}^{-1}$ (Moisture content of $40 \%$, and a cost of the wet biomass of $\left.50 € \mathrm{t}^{-1}\right)$.

When the electricity price is reduced up to $103.00 €$ $\mathrm{MWh}^{-1}$, (Spanish electrical regulation considers a maximum price of $145 € \mathrm{MWh}^{-1}$ ) the profitability is seriously affected. If the investment parameter is not considered as income $\left(300,000 € \mathrm{MW}^{-1}\right.$ year $\left.^{-1}\right)$, NPV and IRR values are significantly reduced. In this case, to reach interesting values of profitability, the wet biomass cost must be reduced to $40 € \mathrm{t}^{-1}\left(0.01429 € \mathrm{kWh}^{-1}\right)$ in a biomass power plant with 50 MWe. Biomass power plants with 15 and 30 MWe reach IRR values below $8 \%$, and therefore, unprofitable projects.

Finally, like wind and solar PV power plants, if only the price in the day-ahead market is considered in the model, the expected profitability parameters are not reached in any of the scenarios that have been analyzed.

\section{References}

1. European Commission. Eurostat. https://ec.europa.eu/eurostat.

2. Menendez J, Loredo J, Fernandez-Oro J, Galdo M. Underground pumped-storage hydro power plants with mine water in abandoned coal mines. In: Proceedings of the IMWA 13th International Congress, 2017; pp. 6-13.

3. Menendez J, Loredo J, Fernandez-Oro JM, Galdo M. Energy storage in underground coal mines in NW Spain: Assessment of an underground lower water reservoir and preliminary energy balance. Renew. Energy 2019; 134:1381-1391.

https://doi.org/10.1016/j.renene.2018.09.042

4. Pujades E, Orban P, Bodeux S, Archambeau P, Erpicum S, Dassargues A. Underground pumped storage hydropower plants using open pit mines: how do groundwater exchanges influence the efficiency? Appl Energy 2017;190:135-46.

5. Menendez J, Ordóñez A, Álvarez R, Loredo J. Energy from closed mines: Underground energy storage and geothermal applications. Renew Sustainable Energy Rev 2019;108:498-512. https://doi.org/10.1016/j.rser.2019.04.007.

6. Menendez J, Loredo J. Use of closured open pit and underground coal mines for energy generation: Application to the Asturias Central Coal Basin (Spain). E3S Web of Conf 2019; 80: 01005. https://doi.org/10.1051/e3sconf/20198001005

7. Menendez J, Fernandez-Oro JM, Galdo M, Loredo J. Pumped-storage hydropower plants with underground reservoir: Influence of air pressure on the efficiency of the Francis turbine and energy production. Renew. Energy 2019; 143:1427-1438. https://doi.org/10.1016/j.renene.2019.05.099

8. Menéndez J, Loredo J. Biomass production in surface mines: Renewable energy source for power plants. Wseas Transactions on Environment and Development 2018;14:205-211.

9. Menéndez J, Loredo J. Reclamation of degraded landscape due to open pit coal mining: Biomass for renewable power plants. Wseas Transactions on Environment and Development 2018;14:251-255

10. Avitabile V, Camia A. An assessment of forest biomass maps in Europe using harmonized national statistics and inventory plots. Forest Ecology and Management 2018; 409:489-498.

11. Thurner, M., Beer, C., Santoro, M., Carvalhais, N., Wutzler, T., Schepaschenko, D., et al., 2014. Carbon stock and density of northern boreal and temperate forests. Global Ecol. Biogeogr. 23 (3), 297-310.

12. Tchanche, Bertrand F., Gr Lambrinos, Antonios Frangoudakis, and George Papadakis."Low-grade heat conversion into power using organic Rankine cycles-A review of various applications." Renewable and Sustainable Energy Reviews 15, no. 8 (2011):3963-3979.

13. Salogni A, Alberti D, Metelli M, Bartanzi R. Operation and maintenance of a biomass fired Organic Rankine Cycle - CHP plant: the experience of Cremona. Energy Procedia 2017; 129:668-675.

14. Mobini M, Sowlati T, Sokhansanj S. Forest biomass supply logistics for a power plant using the discreteevent simulation approach. Appli energy 2011;88(4):1241-1250.

15. González-García S, Bacenetti J. Exploring the production of bio-energy from wood biomass. Italian case study. Sci Tot al Environ 2019;647:158168. doi: 10.1016/j.scitotenv.2018.07.295 